\title{
HSPA4L Gene
}

National Cancer Institute

\section{Source}

National Cancer Institute. HSPA4L Gene. NCI Thesaurus. Code C123144.

This gene is involved in the prevention of protein aggregation. 